\title{
Against Richness of the Base: Evidence from Nganasan ${ }^{\star}$
}

\author{
OLGA VAYSMAN \\ Massachusetts Institute of Technology
}

\section{Introduction}

Since Optimality Theory is a highly output-oriented grammatical theory, the strongest hypothesis is that all systematic, language-particular patterns are the result of output constraints, and that there is no other place from which such patterns can derive. In particular, input is not a level of derivation that can be constrained. This principle is known as Richness of the Base hypothesis, and it states that there are no constraints on the input structure of words, and that all linguistic constraints are statements on the surface structure only. In other words, Richness of the Base attributes all systematic phonological patterns to constraint rankings, not to difference in inputs.

For example, the fact that no English words end in [h] cannot derive from a restriction on English lexicon forbidding [h]-final morphemes. Rather, it must be the case that English grammar forces all its outputs to obey the prohibition on final $[\mathrm{h}]$. It means that even if there were an $\mathrm{h}$-final lexical entry in English, which would provide an [h]-final input, the corresponding output of the English grammar would never be [h]-final. Therefore, the absence of [h]-final words in English must be explained within OT by a grammar - a ranking of constraints with the property that no matter what the input, the output of the grammar will not be [h]-final. In particular, the OT analysis of English must consider a set of inputs to the grammar (the base) that is as rich as possible: the base consists of all universally possible inputs, including those that are [h]-final, those that contain lateral fricatives, those that have lexically marked tone and so on.

In this paper, I consider some consonant gradation facts from a Uralic Samoyedic language Nganasan, and argue that (at least the strict interpretation of) the Richness of the Base hypothesis runs into problems when we deal with full range of relevant data from this language, namely isolated words, compounds, and borrowings.

\footnotetext{
* Many thanks are due to the audiences of BLS 28 and NAPhC 2 for their comments, suggestions, questions and objections. Thanks to Cheryl Zoll and Michael Kenstowicz for support and discussion.
} 


\section{Principles of Consonant Gradation ${ }^{1}$}

Let us begin by defining what consonant gradation is, and how it works in this particular language. The grade alternation, or gradation, of consonants is a phenomenon of alternative appearance of two grades, traditionally called strong and weak, depending on some phonological or morphophonological environment. For Nganasan, consonant grade alternations are alternations between voiceless (strong in traditional terminology) and voiced ("weak") obstruents. The reflexes of gradation are given in table in (1) below:

(1) Gradation reflexes (cf. Helimsky 1998, Tereshenko 1968a) ${ }^{2}$

\begin{tabular}{|l|l|l|l|l|l|l|}
\hline strong grade (voiceless) & h & t & k & s & ç & c \\
\hline weak grade (voiced) & b & ठ & g & J & J & f \\
\hline
\end{tabular}

As we can see from the table, this alternation is basically obstruent voicing alternation. For the purposes of this paper, I will disregard other aspects of the alternations in question, such as place and manner of articulation of the reflexes, and concentrate on the alternation between the grades, so I will refer to the voiceless and voiced series of the consonants.

\subsection{Voicing of Intervocalic Obstruents}

We will now see how principles of Consonant Gradation are responsible for the distribution of obstruent voicing in the language. Intervocalically, obstruents are voiced if they are foot-initial, and voiceless if they are inside a foot. The data in (2) below, which use the $3^{\text {rd }}$ person possessive singular suffix, illustrate this distribution. In the first word, ni-ti 'his/her/its wife', the suffix-initial consonant is inside a foot, and it shows up as voiceless [t]. The same is true for the words for 'his/her/its salmon', 'his/her/its caviar' and 'his/her/its tear' and others: the suffixinitial consonant surfaces as voiceless [t] when it is foot-internal.

Contrast this, for example, with the word fütü- $\partial \ddot{u}$ 'his/her/its hand', where the stem itself constitutes a foot. In this word, the suffix-initial consonant is footinitial, and it appears in its "weak" grade, i.e. as voiced [ð]. The same generalization can be seen in words suuðəə-ðu 'his/her/its lung', məku- $u$ 'his/her/its spine', the word for taa- $\partial u$ 'his/her/its deer', and other words where the consonant of the suffix starts a foot.

\footnotetext{
' Nganasan, also known as Tawgy or Tawgy Samoyed, is a Uralic Samoyedic language, spoken by the north most ethnic group in Eurasia in Taimyr peninsula. About 1300 speakers (1989). The data in this talk is partly taken from source grammars (Helimsky 1998, Tereshenko 1979, Prokofjev 1937) and subsequently checked with native speakers, and partly comes from field work on the language in March 2000 and October 2000. Most of the discrepancies between grammars and my field work are noted.

2 Note on Transcription: IPA transcription for consonants, so palatal consonants will be transcribed as [c], [f], [c], etc., Prenasalized consonants are transcribed with a nasal homorganic superscript nasal, e.g. $\left[{ }^{n} \mathrm{t}\right]$ or $\left.{ }^{\mathrm{g}} \mathrm{g}\right]$. Vowels: symbols traditional for Finnic linguistics: [i], [e], [ü] are front vowels; and [a], [u], [o], [a] and [i] are non-front.
} 
(2) Intervocalic $[t] /[ð]$ gradation, $3^{\text {rd }}$ person possessive suffix - $t V /-ð V$

(nï-tï) 'his/her/its wife'

(jütü)-(ðü) 'his/her/its hand'

(suu)(ðəə)-(ðu) 'his/her/its lung'

(məku)-(ðu) 'his/her/its spine'

(bïnï)-(ðu) 'his/her/its rope'

(kəə)(li-tii) 'his/her/its tear'

(sela)-(ðu) 'his/her/its fat'

(jalï)-(סi) 'his/her/its day'

(yuhu)-(ðu) 'his/her/its mitten'

(Jama)(ða-tu) 'his/her/its animal' (tïri)(mi-ti) 'his/her/its caviar'

(taa)-(ðu) 'his/her/its deer'

(cimi)-( $(\mathrm{i})$ 'his/her/its tooth'

(ninï)-(ðï) 'his/her/its older brother'

(baku)(nu-tu) 'his/her/its salmon'

(kəi)-(ði) 'his/her/its side'

(sürü)-(ðü) 'his/her/its winter'

(noru)(mu-tu) 'his/her/its copper'

(cin te)-(ði) 'his/her/its hill'

(moo)(fa-tu) 'his/her/its stub'

The distribution of voicing is the same whether the gradating consonant starts a suffix or is inside a suffix. In (3) there is another example of the same voicing distribution with a similative suffix, where the gradating consonant $([\mathrm{k}] /[\mathrm{g}])$ is in the second syllable of the suffix. The generalization about voicing distribution still holds: when the obstruent of the suffix is foot-initial, it is voiced, and when it is foot-internal, it is voiceless.

(3) Intervocalic $[\mathrm{k}] /[\mathrm{g}]$ gradation, similative suffix -rəkï/-rəgï

(nï-rə)(gï) 'similar to a woman'

(fütü)-(rəkï) 'similar to a hand'

(bïnï)-(rəkï) 'similar to a rope'

(suu)(ðəə)-(rəki) 'similar to a lung'

(taa)-(rəkï) 'similar to a deer'

(baku)(nu-rə)(gi) 'similar to salmon'

(tïri)(mi-rə)(gï) 'similar to caviar'

(nini)-(raki) 'similar to a brother'

(kəə)(li-rə)(gi) 'similar to a tear'

(kəi)-(rəki) 'similar to a side'

(jama)(ða-rə)(gï) 'similar to an animal'

(yuhu)-(rakii) 'similar to a mitten'

The data in (4) below gives us yet another example of intervocalic obstruent voicing distribution in verbs rather than nouns that we saw before, with a participial suffix with [s]/ [j] alternation. Despite the morphological (nouns vs. verbs) difference, the generalization about consonant gradation is exactly the same: when an intervocalic [s] is foot initial, it voices, and when it is foot-internal it stays voiceless.

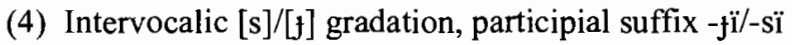

(biti)-(ji) 'drink'

(jilə)-(ji) 'lift'

(jorə)-(fa) 'cry'

(hota)-(fa) 'write out'

(bï)(ð̈ir) (nä tî)-(ji) 'be thirsty, want to drink' (bua?)(tə-sii) 'look up' (bə)(ठua?)(tə-sa) 'grow'

(ho)(ðə?)(tə-sa) 'write'

(jora)(la-sa) 'start crying'

(bï)(đïp)(tii-sï) 'give to drink'

\subsection{Voicing of postconsonantal and coda obstruents}

We will now examine the distribution of voicing in obstruents that are not intervocalic. Nganasan obstruents after another consonant are always voiceless. In 
(5), you see the same suffix as in (2), the $3^{\text {rd }}$ person possessive suffix, but its obstruent always surfaces as voiceless [ $t$ ] after consonant-final stems below, regardless of whether this obstruent is foot-initial or foot-internal:

(5) Postconsonantal (always voiceless), $3^{\text {rd }}$ person possessive suffix $-t \mathrm{~V} /-\varnothing \mathrm{V}$ (tər-tu) 'his/her/its hair' (ka)(đar)-(tu) 'his/her/its light' (bï?-tu) 'his/her/its water' (kam-tu) 'his/her/its blood' (ma?-tu) 'his/her/its house' (he)( $\left.{ }^{\mathrm{n}} \mathrm{fir}\right)-(\mathrm{tu})$ 'his/her/its shaman's drum'(ni)(lu?)-(tu) 'his/her/its life' (huə?)-(tu) 'his/her/its fur overcoat' (ðö)(ru?)-(tu) 'his/her/its cry' (so)(nil)-(tu) 'his/her/its pillow' (bay-tu) 'his/her/its dog'

The same is true of coda obstruents: they are always voiceless in the language. In addition to appearing in their "strong" (i.e. voiceless) grade, coda obstruents in the language are neutralized to glottal stop ${ }^{3}$. The underlying place of articulation, however, is clear in forms where the obstruent is intervocalic, like the Accusative singular forms below:

(6) Coda Obstruents (always voiceless, place neutralization to glottal stop) bï? (cf. Acc. Sg. bïðim with suffix $-m$ and epenthesis) 'water' huə? (cf. Acc. Sg. hiofim with suffix - $m$ and epenthesis) 'fur overcoat' ma? (cf. Acc. Sg. majom with suffix $-m$ and epenthesis) 'house' nilu? (cf. Acc. Sg. nilufim with suffix $-m$ and epenthesis) 'life' ðöru? (cf. Acc. Sg. ðörugum with suffix $-m$ and epenthesis) 'cry' kegu? (cf. Acc. Sg. kekuðum with suffix $-m$ and epenthesis) 'fog' sïnü? (cf. Acc. Sg. sïnügüm with suffix $-m$ and epenthesis) 'memory' hia? (cf. Acc. Sg. hiafim with suffix $-m$ and epenthesis) 'oak'

The two non-intervocalic positions, therefore, are never contrastive as far as obstruent voicing is concerned. The obstruents in postconsonantal and coda positions are voiceless.

\subsection{Obstruent Voicing in Word-Initial Position}

The only position where obstruent voicing is contrastive is word-initial position. Word-initial voicing of the obstruents is not predictable from any principle of Consonant Gradation (or any other principle, as far as I can see). The data in (7) illustrates this point: a word can start with either a voiced or a voiceless obstruent, even though all the word-initial obstruents are also, obviously, foot-initial. With that we have now seen the distribution of voicing of obstruents in all positions; the table in (8) summarizes the distribution.

\footnotetext{
${ }^{3}$ Interestingly enough, the only obstruents that do not get neutralized to glottal stop in the coda are labials. They are also invariably voiceless in the coda position and therefore comprise the alternation $\left[\mathrm{h}^{(\mathrm{w})}\right] \sim[\mathrm{b}] \sim[\mathrm{p}]$.
} 
(7) Word-initial (contrastive voicing)

\begin{tabular}{llll} 
fühü 'sledge' & \multicolumn{1}{c}{ jäte 'stone' } & kita 'cup' & kasu 'bark' \\
cehï 'nail' & çiəjə 'tongue' & gətə 'swan' & gula 'crow' \\
satu 'clay' & sïr 'ice' & tər 'hair' & turku 'lake' \\
bay 'dog', & basa 'iron' & ठöru? 'cry' & ठajpu 'dry wood' \\
h"aa 'tree' & hoðür 'letter' & &
\end{tabular}

(8) Summary of voicing of obstruents

\begin{tabular}{|l|l|l|l|c|}
\hline $\begin{array}{c}\text { Word Position } \\
\text { Prosodic Position }\end{array}$ & Intervocalic & $\begin{array}{l}\text { Post } \\
\text { consonantal }\end{array}$ & Coda & Word-Initial \\
\hline Foot-initial & vcd & vls & - & vcdivls \\
\hline Foot-internal & vls & vls & vls & - \\
\hline
\end{tabular}

As table in (8) illustrates, obstruent voicing in all but one word/prosodic position is predictable. It seems reasonabie to analyze the pattern of Nganasan consonant gradation as intervocalic lenition that is blocked in case an intervocalic obstruent is foot-internal. Obstruent voicing in the language is in complementary distribution everywhere but in word-initial position. Importantly, that position is the only one that has contrastive voicing of obstruents.

\section{No Suffix-Root Asymmetry}

It is also important that the lenition is crucially not a suffix versus root asymmetry, where consonants in suffixes would gradate (lenite) and the ones in the roots would not. In (9) we have an illustration of the same type of consonant alternations we saw before, but within roots. These are the examples which show the alternation between Nominative singular and plural.

(9) Root-internal Grade Alternations - Nominative plural suffix

\section{Nom.sg. Nom.pl. Gloss}

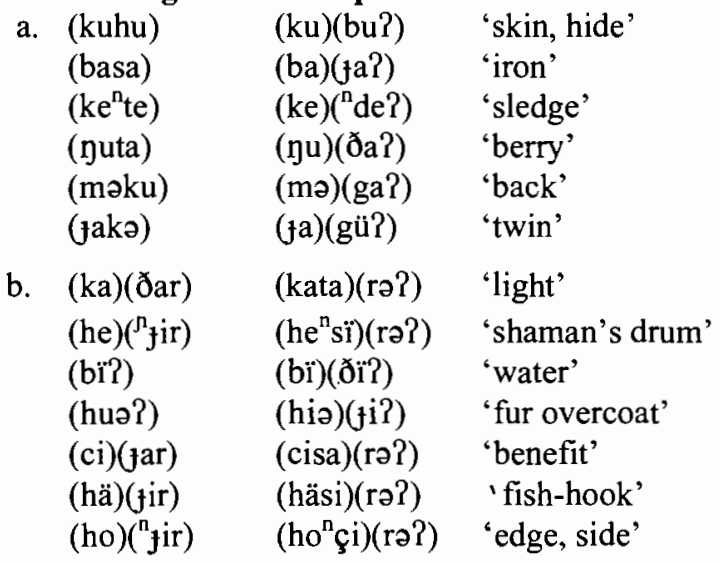


The only difference between Nominative singular and plural in examples in (9a) is that in the plural, a glottal stop is added, thus closing the final syllable. The stems in (9b) have the final syllable closed in the singular (stems of this type are consonant-final stems). When a plural ending, the glottal stop, is added, the resulting complex coda is broken by an epenthetic vowel. The epenthesis changes the foot structure: singular kadar, for example, shows up as katarə? in the plural.

Another example of the same type is in (10). It is an alternation between a noun and an adjective derived from it. The suffix that is added to a noun to create an adjective is a single vowel that takes on the features of the preceding vowel because of vowel harmony. When we add this derivational suffix, the prosodic structure is, again, changed. With vowel-final stems, we get a final CVV foot, and with consonant-final stems, it adds an extra syllable.

\begin{tabular}{|c|c|c|}
\hline $\boldsymbol{t}$ & JTE AI & - Deflomimiral auj \\
\hline Noun & Adjective & Gloss \\
\hline (basa) & (ba)(jaa) & 'iron (noun) - iron (adj)' \\
\hline (ka)(ðar) & (kata)(ra) & 'light (noun) - light (adj)' \\
\hline (bî?) & (bï)(ðiii) & 'water - watery, wet' \\
\hline (ci)(jar) & $($ cisa)(rə) & 'benefit - beneficial' \\
\hline (satu) & (sa)(ðuu) & 'clay (noun) - clay (adj)' \\
\hline (†äte) & $(\jmath a ̈)(ð е ә)$ & 'stone (noun) - stone (adj)’ \\
\hline (ni)(lu?) & $($ nilu)(ju) & 'life - lively' \\
\hline (ma?) & (masa) & 'house - domesticated' \\
\hline
\end{tabular}

The result is that the distribution of voicing of root obstruents is exactly as the distribution of voicing of suffix obstruents: they lenite if they are foot initial and intervocalic, and do not lenite otherwise. The local conclusion from these alternations is that Intervocalic Lenition applies the same way in roots as it does in suffixes: it is restricted by metrical structure, but not by morphological boundaries or morpheme identity (root versus suffix).

\section{Two Basic Models of Complementary Distribution}

Our observation so far is that the only position in the language where we do find contrastive voicing is word-initial position, in every other position the obstruent voicing is in complementary distribution. Logically, complementary distribution can be modeled in two distinct ways, regardless of the framework:

Under the possible first model, principles of consonant gradation require that 1) postconsonantal, coda and foot-internal consonants are voiceless (Fortition), and 2) intervocalic obstruents are voiced (Lenition). In this case, Consonant Gradation would override whatever underlying specifications obstruents have, leaving only word-initial consonants unaffected. Under this approach, there is no need to restrict underlying representations. Whatever the underlying voicing of the obstruents, they surface as voiced or voiceless according to the principles of 
consonant gradation, and only word-initial obstruents will surface with their underlying voicing, because no constraint requires otherwise.

Under another possible analysis, on the other hand, the consonant gradation principle only requires that intervocalic obstruents are voiced (this principle will, of course, be violated if the obstruent is not foot-initial). Consonant gradation adds [+voice] to intervocalic foot-initial obstruents, and does not affect obstruent voicing in any other position. Underspecified obstruents surface as voiceless, and specified word-initial obstruents surface with their underlying voicing. Notice that if this analysis is the right one, crucially there has to be a constraint on underlying representations, namely that only word-initial obstruents have underlying specification for voicing.

\section{Compounds}

Let us now consider another set of data, compounds, that helps us to decide which of the two possible basic analyses is correct. Now, why is this data so important? When a compound is formed, an obstruent that is word-initial (prespecified for voicing) in the lexicon becomes word-internal, which puts it in the right position to be affected by Consonant Gradation. If the first analysis is correct, and consonant gradation overrides any voicing prespecifications, the first obstruent of the second part of the compound should surface as either voiced or voiceless depending on its position in prosody (i.e. voiced if it is both foot-initial and intervocalic, and voiceless otherwise).

If the second analysis is correct, and the principles of consonant gradation operate only on obstruents that are not specified for voicing underlyingly, the initial obstruent of the second root of the compound should surface with its underlying voicing specification, regardless of its position in prosody and whether or not it is intervocalic.

It is important for our task to make sure that the initial obstruent of the second root can be in different prosodic positions, i.e. that the whole compound is one phonological word. Indeed, it seems to be the case that foot boundaries do not have to coincide with edges of the roots in the language: the footing is continuous throughout the compound. The evidence for analyzing a compound as one phonological word comes from two sources: from consonant gradation itself and from the pattern of stress assignment.

\subsection{Compounds as One Phonological Word}

The first piece of crucial data showing that compounds should be analyzed as one phonological word is in (11). In the left column, the feet are assigned continuously from left to right, not respecting the morpheme boundaries. This footing gives us the correct reflex of the gradating consonants. The indicators are not, of course, root-initial consonants but the medial consonants of the second roots which we know adhere to the principles of consonant gradation. Thus, the word kobafa 'earring' (which is a compound of the word ko that means 'ear' and the word basa which means 'iron') shows the "weak", i.e. lenited grade of the 
consonant $s$, indicates that this consonant is foot-initial. In the right column of (11) we see that if we were to start the footing anew with the second root, we would make the wrong predictions for the voicing of this consonant: the compound would surface as kobasa, with the non-lenited strong $s$. Therefore, reflexes of gradation of consonants inside the second root of the compounds establish that a compound is one phonological word.

(11) Compounds (one phonological word, footing continuous)

\begin{tabular}{|c|c|}
\hline $\begin{array}{l}(\text { ciïp)(sinə)(ðəba)(fa) 'bracelet’ } \\
\text { (ciïpsinəðə 'wrist' + basa 'iron') }\end{array}$ & *(ciīp)(sinə)(дə)(basa) \\
\hline $\begin{array}{l}\text { (hïa)(fəki)(ða) 'glove' } \\
\text { (hïaja'thumb' + kita 'cup’) }\end{array}$ & *(hïa)(fə)(kita) \\
\hline $\begin{array}{l}\text { (koba)(fa) 'earring' } \\
\text { (ko 'ear' + basa 'iron') }\end{array}$ & $*($ ko $)($ basa $)$ \\
\hline $\begin{array}{l}\text { (fama)(ðayo)(ga) 'insect' } \\
\text { (łamaða 'animal’ + joka 'numerous') }\end{array}$ & *(jama)(ða)(yoka) \\
\hline $\begin{array}{l}(\text { bï?fü)(bü) 'boat' } \\
\text { (bï? 'water' + fühü 'sledge') }\end{array}$ & *(bï?)(jühü) \\
\hline
\end{tabular}

This conclusion is supported by stress pattern of compounds compared with the stress pattern of words when they are not compounded. The examples in (12) illustrate the stress assignment pattern of the language. Primary stress is marked with double underlining, and secondary with single underlining. The first syllable of the words always receives primary stress, and $3^{\text {rd }}, 5^{\text {th }}$ and so on vocalic moras receive secondary stress.

(12) Stress pattern in words in isolation (non-compounds) ${ }^{4}$

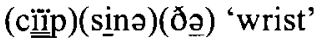

(basa) 'iron'

(hịa)(fo) 'thumb'

(kita) 'cup'

(jama)(ða) 'animal'

(nokka) 'numerous'

When a compound is formed, the stress is assigned exactly as if a compound is a monomorphemic word, i.e. there is only one primary stress, and, even more

\footnotetext{
${ }^{4}$ The stress pattern presented here (trochaic with main stress on the first foot) is the pattern of the Vadey dialect of Nganasan, and is historically original. The other dialect of the language, Avam, has a more complicated pattern of stress assigninent: main stress is on the penultimate mora, with some retractions onto the antepenult from a schwa or [i], provided that the antepenultimate vowel is not itself a schwa. Secondary stress is trochaic, with feet assigned from left to right. That the stress assignment is continuous throughout the compound, however, is true of both dialects.
} 
importantly, the initial vowel of the second root of the compounds does not have to be stressed at all. It receives stress only if the first root of the compound happens to contain an even number of moras.

Again, in the right-hand column we see that if we were to assign stress to the two parts of the compound separately, we would get the wrong predictions for stress, as well as for the reflexes of the gradation.

(13) Stress pattern in compounds (continuous stress assignment throughout)

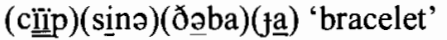

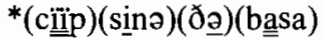

(ciïpsinəðə 'wrist' + basa 'iron')

(hïa)(faki)(ða) 'glove'

*(hịa)(jọ)(ki

(hïafa'thumb' + kita 'cup')

(koba)(ja) 'earring'

*(kô $)($ bassa)

(ko 'ear' + basa 'iron')

(ta

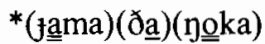

(jamaða 'animal' + noka 'numerous')

(bịîㄱü)(bü) 'boat'

(bï? 'water' + yühü 'sledge')

*(bị̣̂)(yühü)

Both of these sets of data indicate that a compound is treated as one phonological word, and that we can look at compounds to see how obstruents that are wordinitial in the lexicon behave inside phonological words on the surface. The first consonant of the second root of the compound, therefore, can be found both footinitially and foot-internally.

The compounds in (14) suggest that the voicing of the consonant that we are interested in does not depend on any principles of consonant gradation. It surfaces with underlying voicing regardless of its prosodic position. In the word for 'alcohol' which is a compound of a word bitti 'drink' and the word kosü meaning 'dry', the second root of the compound surfaces as voiceless [k] rather than voiced $[\mathrm{g}]$, even though it is both intervocalic and foot-initial. In the word bï? fübü 'boat' (compound of bü? 'water' and fühü 'sledge'), the first obstruent of the second root appears after a consonant (glottal stop), and it is foot-internal. Yet, it does not get devoiced, and surfaces as palatal voiced stop [\}]. It does not get devoiced, even though it is not only foot-internal but also postconsonantal. And, of course, both of these positions are the positions for voiceless, or "strong" grade of obstruents. Apparently, therefore, there is no fortition condition that overrides the underlying voicing specification of this consonant. 
(14) Compounds (underlying voicing preserved)
(jütü)(basa) 'ring'
(yütü 'hand' + basa 'iron')
(h"aa)(jütü) 'branch'
(hua 'tree' + fütü 'hand')
(bïlyü)(bü) 'boat'
*(bïisü)(bü)
(bïl 'water' + fühü 'sledge')
(basa)(cimi) 'shovel'
(basa 'iron' + cimi 'tooth')
*(basa)(fimi)
(bïtï)(kosü) 'alcohol'
(bïtï 'drink' + kosü 'dry')
(hi $\left.{ }^{\mathrm{D}} \mathrm{hi}\right)(\mathrm{ta})(\mathrm{bu})$ 'dawn'
(hi ${ }^{\mathrm{D}} \mathrm{hi}$ 'night' + toabu 'tail')
$($ ko $\delta)($ süo)(kou)(ðaj)(kaa) 'snake'
(koKsüo 'worm'+ kouðajkaa 'long')
*(bïtï)(gosü)
*(hi $\left.{ }^{\mathrm{p}} \mathrm{hi}\right)($ бəə)(bu)
(go $\left.{ }^{\mathrm{g}} \mathrm{hu}\right)($ (?ajep)(ti) 'badmouth, gossip' *(go' hu)(Tasep)(ti)
(no 'hu?a 'bad'+ jeptï 'lip')

The bottom line is that the language can have a voiced obstruent footinternally even when it is intervocalic, but only if this voicing is also present in the input. However, there are no words, outside the compounds, that have specification for voicing anywhere but word-initially. These facts suggest that consonant gradation operates only on obstruents that are underspecified for voicing underlyingly, and cannot override voicing specifications. The second analysis of the phenomenon is correct. The following generalization about underlying representations becomes apparent: all and only word-initial consonants in the language are specified for voicing underlyingly.

\section{Borrowings}

What does this pattern tell us about the Richness of the Base Hypothesis? It is clear that we have a generalization about underlying representations, but we also have to make sure that the language cannot have inputs without the first obstruent specified for voicing (and inputs with voicing specifications anywhere but on the word-initial obstruent), not just that the language does not have such inputs. In other words, we have to show that this principle is an active constraint on underlying representation, rather than merely a coincidence or historical epiphenomenon. To do that, we will now consider borrowings from Russian, which are a potential source of voicing specifications word-internally.

Examples of the borrowings are in (15) below. In the Russian word for "weather" (which means "bad weather" in Nganasan), there are two voiced obstruents, one of which, [g], is foot-internal. It is borrowed into Nganasan as pokoða, with the foot-internal obstruent as voiceless [k]. The voicing of the word-initial obstruent of the source word is preserved. The same is true for all the obstruents in the borrowings: obstruent voicing of the source language is 
preserved always and only word-initially, and the voicing of all word-internal obstruents depends on principles internal to Nganasan, in no way reflecting the voicing in Russian words.

(15) Borrowings (contrastive voicing only word-initially) ðoroga 'paved road' from Russian/doroga/ 'road' pokoða 'bad weather' from Russian /pogoda/ 'weather' *pogoða hapriga 'factory' from Russian/fabrika/ 'factory' *habrika cemnoða 'darkness' from Russian / $\mathrm{t}^{\mathrm{j}}$ emnota/ 'darkness' *cemnota bolka 'Volga' (proper name) from Russian/volga/ 'Volga' *bolga kənigülï 'holidays' from Russian /kanikuli/ 'holidays' * kənikülï solta? 'soldier, police' from Russian/soldat/'soldier' * səlda? çiroða 'orphan' from Russian /sirota/ 'orphan' *çirota səhaga 'little dog, show-dog' from Russian /sobaka/ 'dog' * səbaka

We already know from the compound data that the language does not change the underlying voiced obstruents into voiced on the surface, but rather only regulates the voicing of obstruents that are underspecified for voicing in the input, leaving the specified obstruents with their underlying voicing. The voicing of wordinternal obstruents in the borrowings, however, is predictable and not contrastive.

It follows, therefore, that the borrowings' underlying representations (and crucially not the surface representations) are adjusted to "keep" the obstruent voicing of the source language only word-initially, and to lack voicing prespecifications in all other positions.

\section{Conclusion}

The natural conclusion is that the language restricts its vocabulary. Nganasan inputs have to be constrained in at least one way: all and only word-initial obstruents must be specified for voicing underlyingly. Sets of data from compounding and borrowings, taken together, show us that the constraint on contrastive voicing is an active requirement on underlying representations. This data and analysis provide a clear counterexample to the Richness of the Base hypothesis.

\section{References}

Anttila, Arto 1995. Deriving variation from grammar: A study of Finnish genitives. ROA-63.

Collinder, Björn 1965. An Introduction to Uralic Languages. University of California Press, Berkeley and Los Angeles.

Collinder, Björn 1959. Comparative Grammar of the Uralic Languages. Stokholm: Almqvist \& Wiksell. 
Comrie, Bernard 1981. The Languages of the Soviet Union. Cambridge University Press.

Helimsky, Eugene 1998. Nganasan. In Daniel Abondolo (ed.) The Uralic languages. London, New York: Routledge.

Inkelas, Sharon and Young-mee Yu Cho 1993. Inalterability as Prespecification. Language, 69(3): 529-575.

Kager, Rene 1995. On affix allomorphy and syllable counting. ROA-88.

Prince, Alan 1983. Relating to the grid. $L I, 4: 19-100$.

Prince, Alan and Paul Smolensky 1993. Optimality Theory: Constraint Interaction in Generative Grammar. Ms., Rutgers University, New Brunswick and University of Colorado, Boulder.

Prokofjev, G. 1937. [Прокофьев Г.Н.] Нганасанский (тавгийский) диалект. Языки и письменность народов СССР, ч. 1, Москва.

Setälä, Emil Nestor 1912. Uber Art, Umfang und Alter des Stufenwechsels im Finnisch-Ugrischen und Samojedischen. - Finnisch-Ugrische Forschungen XII Anz., 1-128.

Smolensky, Paul 1995. "On the internal structure of Constraint Component of UG". Handout of a talk given at UCLA, April 7, 1995 ROA 86-0000.

Smolensky, Paul 1996. The initial state and 'Richness of the Base' in Optimality Theory. Technical Report JHU-CogSci-96-4, John Hopkins Univ. ROA-154.

Tereshenko, N. 1962. [Терещенко H.M.] О выражении позессивных отношений в самодийских языках. - Вопросы финно-угорского языкознания, Москва-Ленинград, с. 81-93.

Tereshenko, N. 1968a. [Терещенко Н.M.] Нганасанский язык. - Языки народов СССР, т.3, Москва.

Tereshenko, N. 1968b. [Терещенко Н.M.] К генезису частей речи (на материале самодийских языков). - Вопросы частей речи (на материале языков различных типов), Ленинград.

Tereshenko, N. 1979. [Терещенко Н.M.] Нганасанский язык. Ленинград.

Olga Vaysman

Dept. of Linguistics and Philosophy

Massachusetts Institute of Technology

77 Massachusetts Ave.

Cambridge, MA 02139

olga@mit.edu 